\title{
Study of medical disorders in pregnancy among in patients at a tertiary care hospital in Haryana, India
}

\section{Sushila Chaudhary*, Savita Rani Singhal, Meenakshi B. Chauhan, Anjali Gupta, Monika Dalal}

Department of Obstetrics and Gynecology, PGIMS, Rohtak, Haryana, India

Received: 22 July 2019

Accepted: 14 August 2019

\section{*Correspondence:}

Dr. Sushila Chaudhary,

E-mail: sushilachaudhary68@gmail.com

Copyright: (C) the author(s), publisher and licensee Medip Academy. This is an open-access article distributed under the terms of the Creative Commons Attribution Non-Commercial License, which permits unrestricted non-commercial use, distribution, and reproduction in any medium, provided the original work is properly cited.

\begin{abstract}
Background: Pregnancy is a physiological condition in which various changes occur in pregnant women just to accommodate growing fetus. Pregnancy is a stress test for woman and may unmask certain underlying chronic diseases like, DM, hypertension which were silent or asymptomatic prior to pregnancy. This study was done to know the incidence, type and demographic profile of medical disorders in pregnancy among in patient at a tertiary care hospital.

Methods: It was a retrospective study conducted on 578 patients of medical disorders in pregnancy admitted in a tertiary care hospital from January 2017 to December 2017. Data collected from record room and analysis done.

Results: Total antenatal admissions were 4721. Incidence of medical disorders was $12.24 \%$. Majority of women were in age group 20-30 years (65.5\%). Low-parity (P0, P1). Hypertensive disorders in pregnancy was commonest reported disorder $(42.3 \%)$, followed by hematological disorder $(38.7 \%)$, liver disorder 5\%, endocrine disorder $4.8 \%$, epilepsy $3.8 \%$ and HIV $2.6 \%$ in present study.

Conclusions: Hypertensive disorders were commonest medical disorder followed by hematological, liver, endocrine and epilepsy. All medical disorders in pregnancy to be managed by team approach.
\end{abstract}

Keywords: Anemia, Hypertension, Liver disorders, Medical disorder, Pregnancy

\section{INTRODUCTION}

Pregnancy is a physiological condition in which various changes occur in pregnant women just to accommodate the growing fetus. These changes occur in almost every organ and system like, genital, vascular, metabolic, respiratory, cardiac, hematological and cutaneous changes. Pregnancy is a physiological stress test that unmasks certain underlying chronic diseases like Diabetes mellitus, hypertension, chronic renal disease, cardiac disease and hypercoagubility state. ${ }^{1}$ Some of these chronic diseases are silent or asymptomatic prior to pregnancy. Women with medical disorders should be counselled prior to conception regarding her disease, its effect on pregnancy and complications which may arise during pregnancy. Some medical disorders have long term effects also like GDM have $75 \%$ likelihood of developing type II DM in subsequent five years and with Pre-eclampsia likely to develop CAD and stroke in later life. $^{2}$ Medical complications in pregnancy represent a significant challenge to the healthcare system. ${ }^{3}$ Aim of this study is to know the incidence, type and demographic profile of medical disorders in pregnancy among in patients at a tertiary care hospital.

\section{METHODS}

This was a retrospective study conducted in one unit of department of obstetrics and gyneacology at a tertiary care hospital for a period of one year. 
Study population- case sheets of 578 patients of medical disorders in pregnancy who were admitted in labor room and ward were collected from record room for a period of one year from January 2017 to December 2017 and studied for various parameters.

\section{Inclusion criteria}

- All cases of medical disorders in pregnancy from 28 weeks of gestation onwards were taken.

\section{Exclusion criteria}

- All pregnant women without any medical disorder were excluded from this study.

It was a retrospective study. Case sheets of 578 pregnant women with medical disorders were studied for various parameters like age, residence, parity, period of gestation at the time of presentation and type/subtype of medical disorders in pregnancy in detail.

\section{Statistical analysis}

For all parameters, data collected were tabulated, frequency and percentage were analyzed by using MS excel.

\section{RESULTS}

A total of 578 patients of medical disorder with pregnancy were studied in the study period during January 2017 to December 2017. Total antenatal admissions in this period were 4721. Incidence of medical disorder in pregnancy was $12.24 \%$. Majority of women were in age group $20-30$ years $(65.5 \%)$ Table 1 .

Table 1: Demographic profile of patients.

\begin{tabular}{|lll|}
\hline Residence & Number & Percentage \\
\hline Rural & 306 & 52.9 \\
\hline Urban & 272 & 47.1 \\
\hline Age & & \\
\hline Up to 19 years & 108 & 18.6 \\
\hline 20-30 years & 379 & 65.5 \\
\hline More than 30 years & 91 & 15.7 \\
\hline
\end{tabular}

Mean age: $25.08 \pm 2$

Table 2: Parity distribution.

\begin{tabular}{|lll|}
\hline Parity & Number & Percentage \\
\hline P0 & 198 & 34.2 \\
\hline P1 & 166 & 28.7 \\
\hline P2 & 139 & 24.1 \\
\hline$\geq$ P3 & 75 & 12.9 \\
\hline
\end{tabular}

Mean age was $25.08 \pm 2$. Youngest patient was 17 year and oldest was 40 years old. 63\% women were either conceived for the first time or para one Table 2. More than half $(50.17 \%)$ women presented at 37 weeks of gestation or above, Table 3 .

Table 3: Distribution according to gestational age.

\begin{tabular}{|lll|}
\hline Period of gestation & Number & Percentage \\
\hline 28-32 weeks & 102 & 17.6 \\
\hline $33-36$ weeks & 186 & 32.17 \\
\hline$\geq 37$ weeks & 290 & 50.17 \\
\hline
\end{tabular}

Table 4: Type of medical disorders in pregnancy.

\begin{tabular}{|c|c|c|}
\hline \multicolumn{2}{|c|}{ Type of medical disorder } & Number \\
\hline \multirow{3}{*}{$\begin{array}{l}\text { Hematological } \\
\text { disorder } \\
224(38.75 \%)\end{array}$} & Anemia (nutritional) & 217 \\
\hline & $\begin{array}{l}\text { Thalassemia- } \\
\text { intermedia }\end{array}$ & 1 \\
\hline & Thrombocytopenia & 6 \\
\hline \multirow{3}{*}{$\begin{array}{l}\text { Hypertensive } \\
\text { disorders } \\
245(42.38 \%)\end{array}$} & $\mathrm{PIH}$ & 216 \\
\hline & $\begin{array}{l}\text { Chronic } \\
\text { hypertension }\end{array}$ & 9 \\
\hline & Eclampsia & 20 \\
\hline \multirow{3}{*}{$\begin{array}{l}\text { Endocrine } \\
\text { disorders } \\
28(4.8 \%)\end{array}$} & DM & 10 \\
\hline & Hypothyroidism & 17 \\
\hline & hyperthyroidism & 1 \\
\hline \multirow{4}{*}{$\begin{array}{l}\text { Liver disorders } \\
29(5 \%)\end{array}$} & cholestatis & 8 \\
\hline & \multirow{2}{*}{$\begin{array}{l}\text { Hepatitis } \\
\text { (21) }\end{array}$} & 10 \\
\hline & & 10 \\
\hline & (21) $E$ & 1 \\
\hline \multirow{2}{*}{$\begin{array}{l}\text { Viral diseases in } \\
\text { pregnancy } \\
16(2.7 \%)\end{array}$} & Chicken pox & 1 \\
\hline & HIV & 15 \\
\hline \multirow{2}{*}{$\begin{array}{l}\text { Respiratory } \\
\text { diseases } \\
6(1.03 \%)\end{array}$} & Bronchial asthma & 4 \\
\hline & Tuberculosis & 2 \\
\hline $\begin{array}{l}\text { Neurological } \\
\text { disorder } 22(3.8 \%)\end{array}$ & Epilepsy & 22 \\
\hline \multicolumn{2}{|l|}{ Heart diseases } & 3 \\
\hline \multicolumn{2}{|l|}{ Renal diseases } & 1 \\
\hline \multirow{2}{*}{$\begin{array}{l}\text { Tropical diseases } \\
4(0.69 \%)\end{array}$} & Malaria & 1 \\
\hline & Dengue & 3 \\
\hline
\end{tabular}

Table 5: Sub-types of hypertensive disorders.

\begin{tabular}{|lll|}
\hline Sulb-type & Number & Percentage \\
\hline PIH & 216 & 88.16 \\
\hline Eclampsia & 20 & 8.16 \\
\hline Chronic hypertension & 9 & 3.67 \\
\hline Total & $\mathbf{2 4 5}$ & $\mathbf{1 0 0}$ \\
\hline
\end{tabular}

Hypertensive disorders in pregnancy were most common disorder in our study (42.3\%) including PIH, eclampsia and chronic hypertension followed by anemia, Table 4, and 5.

Hematological disorders other than anemia (nutritional) were thrombocytopenia and 1 patient with thalassemia intermedia, Table 6. 
Table 6: Hematological disorders.

\begin{tabular}{|llll|}
\hline Type & Number & Percentage \\
\hline Anemia & $\begin{array}{l}\text { Nutritional } \\
\text { anemia }\end{array}$ & 217 & 96.8 \\
\cline { 2 - 4 } & $\begin{array}{l}\text { Thallassemia } \\
\text { intermedia }\end{array}$ & 1 & 0.4 \\
\hline Thrombocytopenia & 6 & 2.6 \\
\hline Total & $\mathbf{2 2 4}$ & $\mathbf{1 0 0}$ \\
\hline
\end{tabular}

Liver disorders in pregnancy constituted 5\% including cholestasis and hepatitis, Table 7.

Table 7: Liver disorders in pregnancy.

\begin{tabular}{|llll|}
\hline Type & & Number & Percentage \\
\hline Cholestasis & & 8 & 27.6 \\
\hline Hepatitis & $\mathrm{B}$ & 10 & 34.4 \\
\cline { 2 - 4 }$(21,72.4 \%)$ & $\mathrm{C}$ & 10 & 34.4 \\
\cline { 2 - 4 } & $\mathrm{E}$ & 1 & 3.4 \\
\hline
\end{tabular}

\section{DISCUSSION}

Incidence of medical disorders in pregnancy in present study was $12.24 \%$ which is comparable to the study done by Agwu UM et al (16\%) whereas in another study done by Baral $\mathrm{G}$ et al, incidence of medical disorder was $2.4 \% .^{4,5}$

Our centre being the largest referral centre in Haryana, all high risk pregnancies are referred from different parts of Haryana.

In present study, majority of patients were in age group 20 to 30 years $(65.5 \%)$ mean age being $25.08 \pm 2$ and rural background $(52.9 \%)$ more than urban $47.1 \%$ which is almost similar to the study done by Shrivastava et al which showed $65 \%$ rural versus $35 \%$ urban population and maximum patients were in age group 20-35 (91\%). ${ }^{6}$ Early marriage and completion of family at early age in rural areas is the reason behind this result.

Hypertensive disorders in pregnancy were the most common medical disorders in present study $(42.3 \%)$ including $\mathrm{PIH}(88.16 \%)$, chronic hypertension $(3.68 \%)$ and eclampsia $(8.16 \%)$ while study by $\mathrm{Ye} \mathrm{C}$ et al showed $5.22 \%$ incidence including severe PIH $(39.6 \%)$, chronic hypertension $(3.68 \%)$ and eclampsia $(0.89 \%)$ in their studies. ${ }^{7}$ They analyzed prevalence and risk factors of hypertensive disorders in pregnancy and there were 6 subtypes of hypertensive disorders in their study.

In present study hematological disorders in pregnancy were $38.75 \%$ which included nutritional anemia (96.8\%), thrombocytopenia $2.6 \%$ and one patient with thalassemia intermedia $(0.44 \%)$ while study done by Bora et al 8 showed $89.6 \%$ women had anemia and severe anemia $(\mathrm{Hb}<7 \mathrm{gm})$ were seen in $8.3 \%$ of patients in there. In present study $5 \%$ patients had liver disorders with pregnancy. Among them cholestasis of pregnancy was $27.6 \%$ and hepatitis was $72.4 \%$. (hepatitis B, C and E, $34.8 \%, 34.8 \%$ and $3.4 \%$ respectively) while the study of Dang et al showed incidence of liver disorder $1.32 \%$ including cholestatis of pregnancy $79 \%$ followed by hepatitis B, C and E. ${ }^{9}(0.28 \%, 0.01 \%$ and $0.05 \%$ respectively).

Pregnancy with epilepsy incidence was $3.8 \%$ in present study in comparison to the study done by Raji C et al, which showed $0.6 \% .{ }^{10}$ Incidence of epilepsy in pregnant women in their study.

Endocrine disorders in pregnancy were present in $4.8 \%$ patients. Maximum cases were of hypothyroidism $2.9 \%$ followed by diabetes $1.7 \%$ and hyperthyroidism $0.17 \%$ whereas in a study done by Devi RS et al, incidence of thyroid disorders were $11.6 \% .^{11}$

Other medical disorders in pregnancy were HIV (2.6\%), chicken pox, renal diseases and malaria $0.17 \%$ each, bronchial asthma $0.69 \%$, tuberculosis $0.34 \%$, and cardiac diseases in pregnancy $0.51 \%$.

By seeing pattern of medical disorders in present study, it is clear that almost all type of medical disorders were reported in different proportions. Management of medical disorders in pregnancy is a team management which requires multispecialty team, intensive care setup and team approach for better outcome in these patients.

\section{CONCLUSION}

Hypertensive disorders in pregnancy were most common followed by anemia and liver diseases. Medical disorders in pregnancy constitutes a high risk pregnancy and to be managed by team approach and intensive care setup.

Funding: No funding sources

Conflict of interest: None declared

Ethical approval: The study was approved by the Institutional Ethics Committee

\section{REFERENCES}

1. Vesha GD, Andrea K, Carl RH, Katherine AW. Medical and surgical illnesses during pregnancy: perspectives on immediate and long term out comes. Mayo Clin Proc. 2016;91((9):1151-4.

2. Priscilla PE. Common medical problems in pregnancy: ACP Georgia Chapter Scientific Meeting October $5^{\text {th }} 2013$.

3. William M, Marshall BD, Lindheimer. Medical disorders in pregnancy. J Perinatol. 2002;22(6):511.

4. Agwu UM, Ifebunandu N, Obuna JA, Nwokpo OS, Joannes Umeora OU. Prevalence of medical disorders in pregnancy in Ebonyl State University Teaching Hospital. J Basic Cli Reprod Sci. 2013;2:22-6. 
5. Baral G, Joshi R, Subba P, Pokhrel S, Baree ZA. Medical disorders of pregnancy among Inpatients at tertiary level Hospital. NJOG. 2017;23(1):8-11.

6. Shrivastva S, Malik N. Medical disorders in pregnancy and pregnancy outcome; a retrospective analysis. Int J Reprod Contracept Obstet Gynecol. 2018:7(6):2419-22.

7. Ye C, Ruan Y, Zon I, Li C, Yi C. Survey on hypertensive disorders of pregnancy in China, prevalence risk factors, complications, pregnancy and perinatal outcomes, 2011. PLOS ONE. 2014;9(6):e100180.

8. Bora R, Sable C, Wolfson J, Borok, Ra OR. Prevalence of anaemia in pregnant women and its effect on neonatal outcomes in Northeast India. J Matern Fetal Neonatal Med. 2014:27(9):887-91.

9. Dang A, Agarwal N, Bathla S, Sharma N, Balam S. Prevalence of liver disease in pregnancy and its outcome with emphasis on Obstetric cholestasis; An Indian Scenario. J Obstet Gynecol India. 2010;60(6):413-8.

10. Raji C, Sekar D. Prospective study of feto-maternal outcome in epilepsy in pregnancy in a tertiary care hospital. Int J Reprod Contracept Obstet Gynecol. 2017;6(11):5055-9.

11. Devi RS, Kumari N, Shreen TB, Usha VR. Prevalence of thyroid disorder in pregnancy and pregnancy outcome. JAIM. 2016;3(3):1-11.

Cite this article as: Chaudhary S, Singhal SR, Chauhan MB, Gupta A, Dalal M. Study of medical disorders in pregnancy among in patients at a tertiary care hospital in Haryana, India. Int J Reprod Contracept Obstet Gynecol 2019;8:3770-3. 